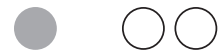

THE JOURNAL OF SOCIAL POLICY STUDIES

Kris Clarke

\title{
ADDRESSING SYSTEMIC RACIAL INJUSTICE IN THE UNITED STATES FROM THE WAR ON POVERTY TO SOCIAL ENTERPRISE TO BLACK LIVES MATTER
}

\begin{abstract}
Despite the many years of reform since the Civil Rights movement, racial justice in the United States has remained elusive because of the endemic nature of racism and anti-Blackness at all levels of American society, including the structures of the welfare state. Using a critical race theory approach, this article examines the evolution of structural social policies from the Great Society of the 1960s to the devolved entrepreneurialism of neoliberalism at the turn of the millennium. If the large-scale social programs of the American welfare state were seen as the only entity with sufficient capacity to collectively change structural racism in the Great Society, neoliberalism brought an austere decentralized vision of social policy that sought to roll back collective security in favor of individual responsibility and risk. Social enterprise emerged in the 1990s as a highly touted method to achieve social justice on the grassroots level amidst the rise of neoliberal ideologies that hollowed out many of the core programs of the American social welfare state. Many extolled the value of social enterprise as a rigorous way to apply efficient business methods to social welfare without taking into account the history of Black enterprise. The neoliberal logic of social enterprise ultimately deters systemic thinking because it focuses on individual abilities and uplift, rather than institutional and structural change. The article ends by reflecting on how the radical imagination of social movements like Black Lives Matter might contribute to achieving racial justice in the United States by re-envisioning collective welfare.
\end{abstract}

Keywords: racial injustice, critical race theory, social enterprise, social welfare, Black Lives Matter

DOI: 10.17323/727-0634-2021-19-1-143-154

Kris Clarke- PhD, Associate Professor, Faculty of Social Sciences (Social Work), University of Helsinki, Finland. Email: kris.clarke@helsinki.fi 
Citizenship in the United States has been marked less by universality than by exclusions: Native Americans were not recognized as US citizens until the Snyder Act of 1924, women obtained the right to vote through the $19^{\text {th }}$ Amendment to the Constitution in 1920, and the civil rights movement of the 1960s fought for Black suffrage. Full citizenship is based on the notion of equality and includes civil, legal and political rights, along with entitlement to the same socio-economic and cultural rights and privileges as other social groups without discrimination (Samito 2009). Yet, voter suppression, biased practices and structural oppression targeted at communities of colour continue to be significant factors in contemporary American society that militate against equity (Anderson, Durbin 2019). Despite the many years of reform since the Civil Rights movement, racial justice has remained elusive because of the endemic nature of racism and anti-Blackness at all levels of American society. Adam Bledsoe (2020:473) defines anti-Blackness as 'a societal logic which assumes the inhumanity and thus spatial illegitimacy of Black populations.' Social welfare policies have closely mirrored the dynamics of racial oppression, although they have often been narrated as instruments that enhance equal opportunities (Davis, Bent-Goodley 2004).

Racism is deeply woven in the fabric of US institutions and infuses every aspect of US public policy from law (Ackermann et al. 2015; Murakawa 2019) to housing (Glotzer 2020) to health (Hoberman 2012) to criminal justice (Alexander 2017) to education (Leonardo, Grubb 2019) to the environment (Williams et al. 2018) to the leadership of philanthropic organizations (Villanueva 2018), creating deeply unequal life opportunities for people of colour. As Critical Race Theory (CRT) postulates, the US system is working exactly as it was designed, namely, to maintain racist hierarchies and practices that uphold whiteness (Delgado 2017).

This article considers how racial injustice in the US has been addressed in policy narratives of social uplift from the War on Poverty of 1964 to the Personal Responsibility and Work Responsibility Act of 1996. Rooted in an historical description of the shift from the welfare state to neoliberalism, namely from the notion of the role of the state as providing a safety net to the state as an austere driver of personal responsibility, the article argues that the policies and practices of social welfare have retained deep structures of racial oppression that militated against racial equity through an 'economy of oppression' that profited from suppressing communities of colour (Reich 2020). The article then considers how the concept of social enterprise (SE) entered into global social policy discourse in the 1990s. Arguing that the social memory of Black enterprise was erased through the presumed novelty of social enterprise during neoliberalism, the article centers the history of Black entrepreneurialism and the ferocious white backlash to its success. It ends with a reflection on emerging visions of racial justice organizing in the $21^{\text {st }}$ century. The analysis is guided by CRT, which places race at the center of critical analysis to challenge colourblind assumptions of social welfare and social uplift. CRT challenges 'the unproblematized Western normative gaze' 
by exposing the deeper structures of racism that shape public policy narratives (Jones 2009:24).

\section{The shifting relationship of social work and the state: from the racialized welfare state to neoliberal social enterprise}

One vision of fighting for racial justice in the US has been to challenge institutions through laws and policies to live up to the democratic egalitarian promises that they espouse. Since the end of slavery, the federal government made many pledges to ensure equality to African Americans from the policies of the Reconstruction to the 1868 adoption of the $14^{\text {th }}$ Amendment which guaranteed equal protection under the law to the Supreme Court ruling in 1954 that outlawed school segregation. For example, Ida B. Wells, an African American journalist and activist in the late $19^{\text {th }}$ and early $20^{\text {th }}$ century, traveled abroad widely to present the moral argument against the extrajudicial murder of Black people by lynching, which was prevalent in the American South (Silkey 2015). Thurgood Marshall, who became the first African American Supreme Court justice in 1967, had a long career of fighting racial injustice through a myriad of local, state and federal court cases (Zelden 2013). Both of these historical figures were deeply engaged with fighting for racial justice by pointing out the hypocrisy of the policies, laws and institutions that proclaimed equality in the US but did not, in fact, ensure that African Americans were treated fairly. The complex lineage of working with and challenging institutions to socially engineer racial justice in the US took place through a myriad of organizations, such as unions (e.g. The Brotherhood of Sleeping Car Porters) and political associations (e.g. The National Association for the Advancement of Colored People) that used their collective influence to improve conditions for Black people.

As Michael Katz (2008) documents, the US welfare state emerged under President Franklin D. Roosevelt during the Great Depression as legislation that codified citizens' mutual responsibilities and social rights. Providing a guarantee against the risks of unemployment, disability, old age, and death, social welfare was initially seen as a collective good that met the needs of the people and mitigated conflicts between labour and capital. However, the welfare system was constructed within the racist social formation of the United States, meaning that the structures of care and support are embedded in longstanding bias (Bonilla-Silva 2001). As Shannon Monnat summarizes (2010: 648): 'Racial outcomes do not come from individual racists per se then but from the crystallization of racial ideologies and justifications for domination in the racial structure based on those ideologies.'

Social citizenship means equal inclusion in the whole range of political, civil and social rights that support equality in society (Revi 2014). Structurally, social citizenship has been undermined in the United States through various governmental interventions that influenced the alleged neutrality of the market and 
access to social rights. Mechanisms such as redlining, where government housing agencies colluded with banks to deny mortgages to black people in predominately white neighborhoods, reinforced deep patterns of racial segregation and inequality that were replicated in health, educational and economic outcomes (Hernandez 2009). Many populations have remained outside of social insurance protections due to racist and sexist structures in the labour market that also pay them far less and provide less economic security. Historically, women, people of colour and people with intersectional identities have faced far more structural and personal barriers to building wealth in American society than white males (Lui et al. 2006). From the beginning, the American welfare state was divided into two spheres: social insurance and anti-poverty entitlements. Social insurance programs, such as social security and unemployment benefits, were largely tied to employment. Anti-poverty benefits, such as aid to dependent children and families, were means-tested and classified as last resort assistance. As Monnat (2010) points out, the US welfare system is infused with gendered and racist structures and practices enveloped in colourblind ideologies that justify differential treatments to diverse racial groups which create stiff barriers to social citizenship.

Declaring a 'war on poverty' in his 1964 State of the Union address, President Johnson's ambitious legislative Great Society program sought to support the nearly $20 \%$ of Americans who were mired in deep poverty (Zelizer 2015). By greatly expanding the federal role in social services and entitlements and creating major programs such as food stamps and Medicaid, the Great Society sought to systematically reduce racial inequality in the US. Together with the 1964 Civil Rights Act (US Public Law 88-352) and 1965 Voting Rights Act (US Public Law 89-110), which outlawed discrimination, Great Society social programs aimed to mobilize the power of the federal government to institute major social change, overriding states that had long histories of racial segregation and discrimination through slum clearance, urban renewal, and community investment (Quadagno 1994). It has been estimated that Johnson's War on Poverty reduced the US poverty rate from $19.5 \%$ to $2.3 \%$ (Burkhauser et al. 2019). Ira Katznelson (2006: 544) argues that Johnson's vision of racial justice failed because he did not recognize the degree to which public policy contributed to reinforcing disparities noting: 'The federal government, though seemingly race neutral, functioned as a commanding instrument of white privilege.' Local authorities maintained control over how programs were managed and often retained long entrenched hierarchies of race, gender, and sexuality in their implementation.

Towards the end of his life, Martin Luther King increasingly recognized the 'arbitrary power' of 'abusive' local welfare bureaucrats (Laurent 2015: 18). King was working on the Poor People's Campaign for economic justice when he was killed. As anti-poverty benefits grew through Great Society programs, recipients became increasingly racialized and gendered (Winter 2006). The term 'welfare' thus became stigmatized and viewed as a handout to unmarried women and people of colour, while social insurance programs like social security were widely 
seen as an earned right by white workers. The advances of the Great Society to extend many of Roosevelt's New Deal social programs through poverty alleviation were nonetheless filtered through the patchwork of particularistic state policies. These policies often retained local practices of supporting racial disparities by excluding some categories of workers that have a disproportionate amount of people of colour, such as farm labourers, child minders and housekeepers, from full inclusion in benefits and protection systems.

As the American welfare state ramped up anti-poverty programs, explanatory theories emerged in the 1960s to examine why poverty in African American communities remained despite governmental efforts. Postwar American social work theories often focused on culture as a driver of behaviour, many times at the expense of social structural analysis (Curran 2003). The 'culture of poverty' held that the values, beliefs and attitudes of people determine their behaviour, even if structural conditions might change (Lewis 1959). Further, the 1965 Moynihan report on Black families saw them as entangled in social pathologies due to the historical trauma of slavery and structural poverty. The Moynihan report focused largely on the need to support patriarchal family structures as a remedy for structural white racism (Geary 2011). These scholars were criticized as maintaining a 'blame the victim' approach to poverty (Briggs 2019). Mario Luis Small et al. (2010: 9) noted that while there were many different cultural values that influenced behaviour, 'the greatest barrier to middle-class status among the poor is sustained material deprivation itself.' Sandra Susan Smith (2007) argued that the belief in individualism as the main determinant of success in the American Dream often undermined people in their quest for achievement because they did not utilize networks or social connections.

When Ronald Reagan ran for president in 1980, the racialized image of the 'welfare queen in designer jeans' firmly linked public welfare recipients with race and gender, discrediting those who received social support while offering tax cuts for the wealthy (Dudas 2009). Reagan's vision of a slimmed down neoliberal government associated with economic liberalization as the core of the American Dream eventually crossed party lines reifying the individual over the collective. By 1996, Democratic President Bill Clinton sought to 'end welfare as we know it', gutting the American safety net with the Personal Responsibility and Work Opportunity Reconciliation Act of 1996 (Chappell 2011). This welfare reform fundamentally changed how social welfare was distributed, dismantling collective notions of social rights and common responsibility by increasing the depth of inequality, especially among racial minorities. Instead of the federal government distributing funds as part of social rights, it now gave it in largely unrestricted devolved block grants to states to administer as they saw fit according to local standards and traditions. Further, Clinton's welfare reform introduced the elimination of the statutory entitlement to poverty relief, created time limits on assistance over a lifetime, and restricted eligibility for food stamps. Clinton's neoliberal restructuring brought a return to the model of the 
poorhouse, forcing people to 'earn their subsistence in a labour market which, prior to welfare, had already rejected them' (Patriquin 2001: 73). Neoliberalism thus reversed the social protections of the welfare state, emphasizing individual risk over collective responsibility, which fundamentally retrenched efforts to address racial equality in the United States.

\section{Taking responsibility- constructing social enterprise as a color-blind solution to endemic racism}

There have always been a wide variety of faith-based and nonprofit organizations throughout American history, but the notion of SE which emerged in the US during neoliberalism tended to focus on individual business models that sought to make a social impact through corporate responsibility and creating social value (Defourny, Nyssens 2010). Arguing that neither government nor charity was sufficient to solve poverty, social business was seen as an enterprise that sought to retain a capitalist profit-maximizing model, while employing workers and creating products consistent with a social objective (Yunus 2007). This perspective viewed the marketplace as the source of competition and excellence, but also rendered the economy of oppression invisible through an ahistorical view of how capitalism emerged in the US. White wealth was extracted from the enslaved labor of black bodies, siphoned from the exploited work of new immigrants and transferred from stolen Indigenous lands (Nummi et al. 2019). As described in the previous section, racialized structures of social citizenship maintained firm barriers that mitigated against leveling the playing field of opportunity.

If the large-scale social programs of the welfare state were narrated as the only entity with sufficient capacity to collectively change structural racism in the Great Society, neoliberalism brought an austere version of social policy that placed the burden of change on individuals. SE was viewed as a means to empower diverse communities through market-based solutions to racial injustice in response to the seeming failure of large-scale systems to adequately redress inequality. However, SE has also been criticized as piecemeal and inadequate to make systemic change because it does not challenge the status quo due to its entrenchment in capitalism.

The use of market-based language in social policy narratives eroded the collective social justice mission of government by placing the burden of economic uplift on individuals themselves, relegating social workers to bureaucratic managerial positions (Pollack, Rossiter 2010). Social enterprises sought to fulfill needs unmet by social welfare interventions by applying a neoliberal logic that human welfare can best be served by liberating human freedom by unleashing the power of entrepreneurial market freedom. In this logic, welfare is less about the redistribution of resources than the responsibility of the individual to get aid in exchange for work in a competitive environment (Amable 2011). While SE offers the promise of resilience and self-sufficiency through enterprise, it also forces 
individuals to adapt to the conditions of the market rather than providing mutual aid to support one another. SE uses words like risk, accountability, engagement, and responsibility. Social enterprises are nonetheless limited by the structures that shape the playing rules of business. Many studies have pointed out that structural factors such as social networks and access to resources have a disproportionate impact on ethnic minority-run enterprises (Portes, Rumbaut 2006).

The rise of social entrepreneurship as a policy construct in tandem with market-oriented ideologies during neoliberal political regimes at the end of the 1990s reflected less a novel way of understanding social uplift than a way of constructing entrepreneurialism as the solution to complex community social issues. Neoliberal ideologies in the 1990s rolled back welfare state policies repackaging narratives of racial equality as the responsibility of the individual. Viewing the welfare state as based on a static and archaic model of full employment with heteronormative male heads of household, SE underlined the need for nimble and innovative solutions to pressing social problems in complex societies that increasingly lack social cohesion. Charles Leadbeater (1997:3) argued that social enterprise offers opportunities for diverse communities to develop critical social capital to empower self-reliance through non-hierarchical and non-traditional leadership. SE advocated for the use of business methods for altruistic reasons to resolve social issues such as homelessness and poverty through microfinance, philanthropy, and businesses that employ vulnerable people. Narratives of social enterprise, however, often existed in a historical vacuum that did not take into account the role of structural racism both in creating the social problems and preventing solutions. As Michael Perez and Phia Salter (2019) summarize, neoliberalism promotes a color-blind ideology by reducing racial injustice to individual deficits.

There are deep historical roots of communitarianism through self-reliance within African American communities. As Ashanté Reese (2018:411) points out: "'Black communities" investment in self-reliance as a political and cultural framework for communal uplift has been central to intellectual thought and activist strategizing.' As such, Reese argues that African American entrepreneurialism has never really been seen as solely an individual enterprise but also embodied dimensions that provided social uplift in Black communities. Maggie Lena Walker (1867-1934), the daughter of a slave, became the leader of a fraternal organization dedicated to black social and economic advancement as a teenager and later founded the first black bank in the US. The aim of Walker's work was to uplift the Black community through entrepreneurialism: '[she] emphasized the racial uplift aspect of business and the type of community organization she thought was needed to support economic and social development. ... Like many leaders of her time, Walker called for racial unity, racial pride, racial love, and racial cohesiveness' (Marlowe 2003: 63-64).

The Greenwood District of Tulsa, Oklahoma was also known as 'Black Wall Street' in the early $20^{\text {th }}$ century due to its abundance of economic activity. As a local Black newspaper of the time proclaimed: 'Let us make employment 
for our own. To do so means race independence and progress ... Keep as much wealth as possible within the race. The future will take care of itself' (Tulsa Star 1918). However, in 1921 one of the deadliest race riots took place when whites stormed Greenwood inflicting mass casualties and destroying the thriving community (Messer et al. 2018). Similar pogroms took place throughout the US where white mobs, who felt their hegemony was threatened, extinguished Black economic progress. African Americans were not compensated for their losses. What this history demonstrates is that the entrepreneurial spirit and drive of Black communities has never been sufficient to withstand the violence of the racist structures of the US economy of oppression. Despite the War on Poverty and the 'empowerment' of individual responsibility through over 30 years of neoliberal governance, racial wealth disparities remain as profound as ever (Sullivan, Meschede 2018). The historical amnesia and neoliberal orientation of SE fruitlessly constructs colour-blind peace and discriminatory justice as solutions to racial injustice (Perez, Salter 2019:281).

\section{Black Lives Matter and the radical imagination}

The recent protests that have rocked the United States may prove to be a turning point in how racial justice is discussed and remedied in American society. Nearly a half million people in over 550 places across the US protested on 6 June 2020 and 15-26 million people have participated in Black Lives Matter (BLM) demonstrations since the murder of George Floyd (Buchanan et al. 2020). As Jozie Nummi et al. (2019: 1043) point out: 'This historical resistance is necessary because in the U.S. case, systemic racism is based on a broad white racial frame (worldview) that penetrates all social institutions, public consciousness, and political bodies.' The 2020 protests for racial justice in the US have come at the confluence of the global COVID-19 pandemic, encroaching climate crisis, intensifying white supremacist violence, and massively growing inequality. These protests are firmly embedded in the trajectory of a long tradition of Black resistance to anti-Blackness, white supremacy and the failure of American society to tackle racial injustice.

Initiated by three Black women, Black Lives Matter (BLM) represents a decentred and non-hierarchical movement emerging from the tradition of the Black radical imagination, bringing a critical lens to community organizing by centring intersectional inequality (Méndez 2016). BLM thus does not represent a singular voice or view but opens up a rich intersectional conversation on how to remedy the anti-Blackness at the core of societal structures in the United States. Through the disruption of everyday life to draw attention to anti-Black issues, deep engagement in how anti-Blackness plays out in complex practices on local levels, and strategic organizing for resistance, BLM has trained a spotlight on state-sanctioned violence against Black people catalyzing a broad movement for racial justice. In assembling a decentralized coalition of groups organizing 
against police violence and racism, BLM is united by principled beliefs including accountability, empathy, collective value, restorative justice, queer affirming, black women, and loving engagement (Taylor 2017). As activist Charlene Carruthers (2018: 139) wrote: 'Our collective imaginations must burst open to believe liberation is possible.' Firmly following in Black traditions of 'self-help, race, pride, mutual aid and social debt' (Carlton-LaNey 1999:311), BLM has organized to elect representatives to local, state and federal offices and challenges traditional strategies of addressing racial injustice through social policy or social enterprise. BLM represents an emancipatory leap of moving towards a radically reimagined society in calling for decolonizing American history, recognizing and embracing the diversity of identities of people living in the US, and seeking new solutions to social injustice and wellbeing that have not been met through the social welfare efforts of the Great Society or social enterprise of neoliberalism.

\section{Conclusions}

In her book on the Black Lives Matter movement, eminent Black historian and activist Barbara Ransby (2018: 163) quotes cultural theorist Homi Bhabha's observation that 'a state of emergency is a state of emergence' to reinforce the significance of the current transformative moment. If the trajectory of $20^{\text {th }}$ century American society was to bolster white supremacy by parcelling out limited support to Black communities through circumscribed social policies that heaved blame on the backs of the most oppressed while doling out limited resources, the 1990s neoliberal turn towards a discourse of 'personal responsibility' through competing in the 'free market' masked the deeply unequal structural position of Black people in the U.S. Throughout American history, Black communities have actively challenged the multitude of barriers to accessing resources as well as the invidious nature of anti-Blackness at all levels of society. According to Robin D. G. Kelley (2002), the radical Black imagination has deep roots in the long history of Black resilience, resistance and joy in the continuing struggle for full emancipation. Its central message that a socially just society cannot emerge within structures that are fundamentally unjust, such as racism, patriarchy, heteronormativity and capitalism, opens possibilities to radically reimagine how we live together through accountability, empathy, and restorative justice.

\section{Acknowledgement}

Special thanks to Dr. Lisa D. Moore for her insightful critique and comments.

\section{References}

Ackermann N., Goodman M. S., Gilbert K., Arroyo-Johnson C., Pagano M. (2015) Race, Law, and Health: Examination of 'Stand Your Ground' and Defendant Convictions in Florida. Social Science \& Medicine, (142): 194-201. 
Alexander M. (2017) The New Jim Crow: Mass Incarceration in the Age of Colorblindness. New York: New Press.

Amable B. (2011) Morals and Politics in the Ideology of Neoliberalism. Socio-Economic Review, 9 (1):3-30.

Anderson C., Durbin R. J. (2019) One Person, No Vote: How Voter Suppression is Destroying our Democracy. New York: Bloomsbury Publishing.

Bledsoe A. (2020). The Primacy of Anti-blackness. Area (London 1969), 52 (3): 472-479.

Bonilla-Silva E. (2001) White Supremacy and Racism in the Post-civil Rights Era. Boulder, CO: Lynne Rienner.

Briggs L. (2019) Reproducing Empire: Race, Sex, Science, and U. S. Imperialism in Puerto Rico. Berkeley: University of California Press.

Buchanan L., Bui Q., Patel J.K. (2020) Black Lives Matter May Be the Largest Movement in U. S. History. New York Times. July 3, 2020.

Burkhauser R.V; Corinth K., Elwell J., Larrimore J. (2019) Evaluating the Success of President Johnson's War on Poverty: Revisiting the Historical Record Using a Full-Income Poverty Measure. NBER Working Paper No. 26532.

Carlton-LaNey I. (1999) African American Social Work Pioneers' Response to Need. Social Work, 44 (4):311-321.

Carruthers C. (2018) Unapologetic: A Black, Queer, and Feminist Mandate for Radical Movements. Boston: Beacon Press.

Chappell M. (2011) The War on Welfare: Family, Poverty, and Politics in Modern America. Philadelphia: University of Pennsylvania.

Curran L. (2003) The Culture of Race, Class, and Poverty: The Emergence of a Cultural Discourse in Early Cold War Social Work (1946-1963). Journal of Sociology \& Social Welfare, 30 (3): 15-38.

Davis K. E., Bent-Goodley T.B. (2004) The Color of Social Policy. Alexandria, VA: Council on Social Work Education.

Defourny N., Nyssens M. (2010) Conceptions of Social Enterprise and Social Entrepreneurship in Europe and the United States: Convergences and Divergences. Journal of Social Entrepreneurship, 1 (1):32-53.

Delgado S. (2017) Critical Race Theory (Third Edition). New York: New York University Press.

Dudas J. (2009) Little Monsters, Wild Animals, and Welfare Queens: Ronald Reagan and the Legal Constitution of American Politics. Studies in Law, Politics and Society, (49): 157-210.

Geary D. (2011) Racial Liberalism, the Moynihan Report \& the 'Dædalus' Project on 'The Negro American.' Daedalus (Cambridge, Mass.), 140 (1): 53-66.

Glotzer P. (2020) How the Suburbs were Segregated: Developers and the Business of Exclusionary Housing, 1890-1960. New York: Columbia University Press.

Hernandez J. (2009) Redlining Revisited: Mortgage Lending Patterns in Sacramento 19302004. International Journal of Urban and Regional Research, 33 (2):291-313. 
Hoberman J.M. (2012) Black and Blue: The Origins and Consequences of Medical Racism. Berkeley: University of California Press.

Jones R. (2009) Philosophical Methodologies of Critical Race Theory. Georgetown Journal of Law \& Modern Critical Race Perspectives, 1 (1): 17-39.

Katz M.B. (2008) The Price of Citizenship: Redefining the American Welfare State. Philadelphia: University of Pennsylvania Press.

Katznelson I. (2006) When Is Affirmative Action Fair? On Grievous Harms and Public Remedies. Social Research, 73 (2): 541-568.

Kelley R. (2002) Freedom Dreams: The Black Radical Imagination. Boston: Beacon Press.

Laurent S. (2015) The Unknown Story of a Counter-war on Poverty: Martin Luther King's Poor People's Campaign. Stanford, CA: Stanford Center on Inequality and Poverty Working Paper.

Leadbeater C. (1997) The Rise of the Social Entrepreneur. London: Demos.

Leonardo Z., Grubb W. N. (2019) Education and Racism: A Primer on Issues and Dilemmas. New York: Routledge.

Lewis O. (1959) Five Families: Mexican Case Studies in the Culture of Poverty. New York: Mentor Books.

Lui M., Robles B., Leondar-Wright B., Brewer R., Adamson R. (2006) The Color of Wealth: The Story behind the U.S. Racial Wealth Divide. New York: New Press.

Marlowe G. W. (2003) A Right Worthy Grand Mission: Maggie Lena Walker and the Quest for Black Economic Empowerment. Washington, DC: Howard University Press.

Méndez X. (2016) Which Black Lives Matter?: Gender, State-Sanctioned Violence, and 'My Brother's Keeper.' Radical History Review, (126): 96-105.

Messer S., Shriver T., Adams A. (2018) The Destruction of Black Wall Street: Tulsa's 1921 Riot and the Eradication of Accumulated Wealth: The Destruction of Black Wall Street. The American Journal of Economics and Sociology, 77 (3-4): 789-819.

Monnat S. (2010) Toward a Critical Understanding of Gendered Color-Blind Racism within the U.S. Welfare Institution. Journal of Black Studies, 40 (4): 637-652.

Murakawa N. (2019) Racial Innocence: Law, Social Science, and the Unknowing of Racism in the US Carceral State. Annual Review of Law and Social Science, 15 (1): 473-493.

Nummi J., Jennings C., Feagin J. (2019) BlackLivesMatter: Innovative Black Resistance. Sociological Forum (Randolph, N.J.), (34): 1042-1064.

Patriquin L. (2001) The Historical Uniqueness of the Clinton Welfare Reforms: A New Level of Social Misery. Journal of Sociology and Social Welfare, 28 (3): 71-94.

Perez S., Salter P. (2019) Trust, Innocence, and Individual Responsibility: Neoliberal Dreams of a Colorblind Peace. Journal of Social Issues, 75 (1):267-285.

Pollack S., Rossiter A. (2010) Neoliberalism and the Entrepreneurial Subject: Implications for Feminism and Social Work. Canadian Social Work Review, 27 (2): 155-169.

Portes A., Rumbaut R. (2006) Immigrant America: A Portrait. Berkeley: University of California Press. 
Quadagno J. (1994) The Color of Welfare: How Racism Undermined the War on Poverty. Oxford: Oxford University Press.

Ransby B. (2018) Making All Black Lives Matter: Reimagining Freedom in the $20^{\text {th }}$ Century. Berkeley: University of California.

Reich R. (2020) On the Profitability of Racism. Salon. Available at: https://www.salon. com/2020/11/30/robert-reich-on-the-profitability-of-racism_partner/ (accessed 15 October 2021).

Reese A. (2018)'We Will not Perish; We're Going to Keep Flourishing': Race, Food Access, and Geographies of Self-Reliance. Antipode, 50 (2): 407-424.

Revi B. (2014) T.H. Marshall and His Critics: Reappraising 'Social Citizenship' in the Twenty-First Century. Citizenship studies, 18 (3-4): 452-464.

Samito C. (2009) Becoming American under Fire: Irish Americans, African Americans, and the Politics of Citizenship during the Civil War Era. Ithaca: Cornell University Press.

Silkey S. (2015) Black Woman Reformer: Ida B. Wells, Lynching, and Transatlantic Activism. Athens, GA: University of Georgia Press.

Small M. L., Harding D., Lamont M. (2010) Introduction: Reconsidering Culture and Poverty. The Annals of the American Academy of Political and Social Science, (629): 6-27.

Smith S. (2007) Lone Pursuit. New York: Russell Sage Foundation.

Sullivan L., Meschede T. (2018) How Measurement of Inequalities in Wealth by Race/Ethnicity Impacts Narrative and Policy: Investigating the Full Distribution. Race and Social Problems, 10 (1): 19-29.

Taylor K. Y. (2017) How We Get Free: Black Feminism and the Combahee River Collective. Chicago: Haymarket Books.

Tulsa Star (1918) Insure the Race's Future. January 19: 4.

United States Public Law 88-352. The Civil Rights Act of 1964.

United States Public Law 89-110. The Voting Rights Act of 1965.

Villanueva E. (2018) Decolonizing Wealth: Indigenous Wisdom to Heal Divides and Restore Balance. Oakland, CA: Berrett-Koehler Publishers, Inc.

Williams H., Kim D., Nishime L. (2018) Racial Ecologies. Seattle: University of Washington Press.

Winter N. (2006) Beyond Welfare: Framing and the Racialization of White Opinion on Social Security. American Journal of Political Science, 50 (2): 400-420.

Yunus M. (2007) Creating a World without Poverty: Social Business and the Future of Capitalism. New York: Public Affairs.

Zelden C. (2013) Thurgood Marshall: Race, Rights, and the Struggle for a More Perfect Union. London: Routledge.

Zelizer J. (2015) The Fierce Urgency of No: Lyndon Johnson, Congress, and the Battle for the Great Society. New York: Penguin. 